\title{
EVALUASI ANTARMUKA WEBSITE SMK MUHAMMADIYAH 2 SRAGEN MENGGUNAKAN METODE USABILITY TESTING
}

\author{
Lucky Satrya Wiratama \\ Fakultas Teknik Elektro dan Informatika, Program Studi Teknik Informatika \\ Universitas Surakarta \\ Email: satrya.lucky@gmail.com \\ Dimas Sasongko \\ Fakultas Teknik Elektro dan Informatika, Program Studi Teknik Informatika \\ Universitas Surakarta \\ Email: dimas@unsa.ac.id
}

\begin{abstract}
ABSTRAK
Website sekolah berisi tentang fitur pendidikan yang bertujuan untuk memberikan informasi dan layanan tentang sebuah sekolah kepada pengguna. Oleh karena itu untuk mencapai tujuan dari website sekolah maka perlu dilakukan evaluasi usability untuk mengetahui tingkat kemudahan, kenyamanan, dan kepuasan ketika menggunakan website sekolah. Website SMK Muhammadiyah 2 Sragen memungkinkan untuk dikunjungi oleh beragam orang dengan latar belakang yang berbeda-beda, sehingga perlu dilakukan evaluasi untuk mengetahui tingkat kemudahan, kenyamanan, dan kepuasan pengguna ketika menggunakan website. Masalah dalam penelitian ini adalah mengetahui kinerja tampilan antarmuka dan masalah usability website. Tujuan dari penelitian ini adalah mengetahui kinerja website dengan metode usability testing yang kemudian nantinya akan memberikan masukan dalam proses pengembangan website. Metode dalam penelitian ini adalah metode usability testing. Pengujian dilakukan dengan memberikan penugasan kepada responden untuk berinteraksi dengan website dan menggunakan kuesioner. Hasil dari penelitian ini adalah implementasi menu/navigasi website tidak efektif pada pengguna perangkat mobile, hal ini dibuktikan dengan adanya perbedaan waktu rata-rata yang lebih lama antara pengguna perangkat mobile dengan pengguna perangkat desktop.
\end{abstract}

Kata kunci: website, antarmuka, pengujian usability.

\section{ABSTRACT}

The school website contains about education that aims to provide information and services about a school to the user. Therefore, to achieve the goals of the school website so need to do usability evaluations to find out the level of ease, comfort, and satisfaction when using the school website. Website of SMK Muhammadiyah 2 allows for Sragen is visited by different people with different backgrounds, so that evaluation needs to be done to find out the level of ease, convenience, and user satisfaction when using the website. The problem in this research is to know the performance of the display interface and usability website. The purpose of this research is to know the performance of website usability testing methods which then will be providing input into the process of website development. The method in this research are methods of usability testing. Testing is done by giving the assignment to the respondents to interact with websites and using questionnaires. The results of this research are implementations of menu/navigation website is not effective on the user's mobile device, this is evidenced by the existence of the average time difference longer between users of mobile devices with the desktop device users.

Keywords: website, user interface, usability testing.

\section{PENDAHULUAN}

Pengembangan sebuah website harus melalui beberapa pedoman usability untuk memastikan bahwa tujuan dari website dapat dicapai. Oleh karena itu pengembangan situs web harus sesuai dengan kebutuhan pengguna sehingga pengembang perlu melakukan evaluasi website. Sayangnya website dan pengembangannya sering di dorong oleh faktor teknologi, struktur organisasi dan tujuan bisnis, bukan oleh kebutuhan pengguna. Prinsip utama yang dijadikan ukuran keberhasilan pengembangan sistem informasi dan website adalah usability. Tingkat usability menentukan apakah sistem tersebut akan bermanfaat, diterima user dan bertahan lama dalam penggunaannya. Sistem dengan usability yang tinggi akan membuat sistem tersebut populer dalam waktu lama dan luas penggunaannya karena banyak orang akan merasakan kemudahan dan manfaatnya. 
Website SMK Muhammadiyah 2 Sragen memungkinkan untuk dikunjungi oleh beragam orang dengan latar belakang yang berbeda-beda, sehingga perlu dilakukan evaluasi untuk mengetahui tingkat kemudahan, kenyamanan, dan kepuasan pengguna ketika menggunakan website SMK Muhammadiyah 2 Sragen. Metode yang akan digunakan dalam evaluasi website menggunakan metode usability testing seperti yang terlihat pada Gambar 1. Pengambilan data pengujian usability testing pada penelitian ini menggunakan pengukuran kemampuan dan kuesioner. Pengukuran kemampuan dapat dilakukan dengan menggunakan kebiasaan yang dilakukan oleh pengguna dan menggunakan pemberian tugas kepada pengguna untuk menyelesaikan sebuah skenario yang sudah disiapkan [1]. Pengukuran kemampuan yang dilakukan pada penelitian ini menggunakan pemberian tugas kepada pengguna.

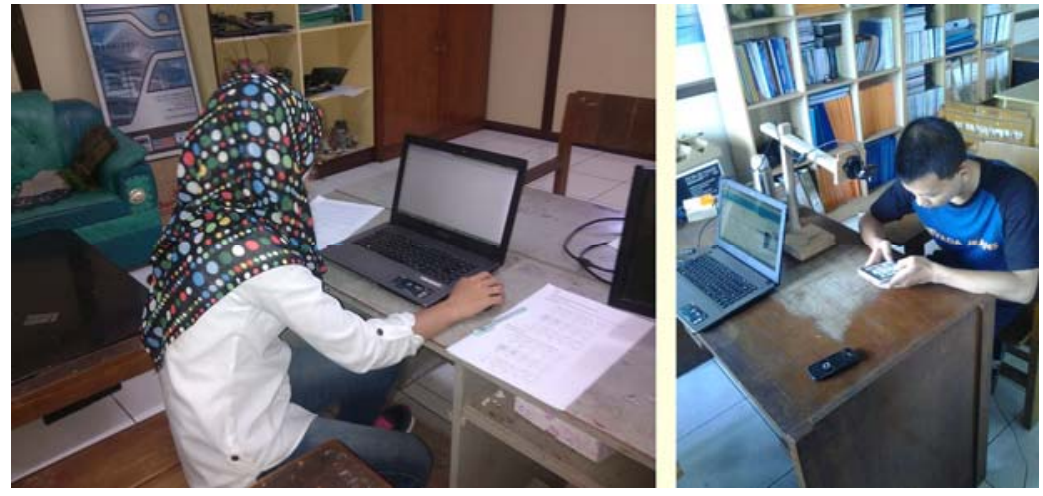

Gambar 1. Pengujian Usability [2]

Metode usability sudah digunakan oleh peneliti sebelumnya untuk mengetahui kinerja tampilan antarmuka dan masalah yang terdapat pada antarmuka. Penelitian sebelumnya oleh Purwani Istiana [3] menggunakan metode usability untuk mengetahui apakah mahasiswa merasakan efektifitas, efisiensi dan kepuasan penggunaan situs web Perpustakaan UGM. Penelitian ini mengambil sampel mahasiswa UGM yang sedang dan atau pernah menggunakan situs web Perpustakaan UGM. Hasil analisis menunjukkan bahwa situs web Perpustakaan UGM bermanfaat bagi mahasiswa. Purwani Istiana dan Eko Nugroho [4] melakukan penelitian menggunakan metode usability untuk mengetahui apakah mahasiswa merasakan efektifitas penggunaan, efisiensi penggunaan, dan kepuasaan penggunaan dari situs web Perpustakaan Fakultas Geografi UGM. Penelitian dilakukan dengan kuisioner yang diberikan kepada responden (mahasiswa), pengambilan sampel dilakukan secara acak kepada 100 mahasiswa yang pernah menggunakan situs web Perpustakaan UGM. Hasil yang dicapai pada penelitian berdasarkan hasil analisis adalah situs web Perpustakaan Fakultas Geografi UGM bermanfaat bagi mahasiswa yang berarti memiliki tingkat usability bernilai baik. Penelitian Wahyu Hidayat dkk [5] adalah mengukur tingkat kemudahan, tingkat kecepatan, jumlah kesalahan, dan tingkat kepuasan pengguna menggunakan metode usability testing. Hasil yang diperoleh dari penelitian akan memberikan masukan untuk pengembangan situs web Pemerintahan Kota Prabumulih.

Penelitian yang akan dilakukan oleh peneliti memiliki perbedaan pada pengambilan data pengujian usability. Pada penelitian sebelumnya pengambilan data uji usability dilakukan menggunakan kuisioner, sementara pada penelitian ini pengujian dilakukan dengan menggunakan skenario pengujian dan menggunakan kuisioner. Tujuan dari penelitian yang dilakukan adalah untuk mengetahui kinerja dan mengetahui masalah kebergunaan pada website SMK Muhammadiyah 2 Sragen. Hasil dari penelitian dapat digunakan sebagai masukan untuk pengembangan website SMK Muhammadiyah 2 Sragen.

\section{METODOLOGI PENELITIAN}

Metode penelitian yang digunakan dalam penelitian ini terdiri dari (1) tahapan penelitian, (2) alat dan bahan, dan (3) perancangan pengujian usability.

\subsection{Tahapan Penelitian}

Metode penelitian diawali dengan tahapan penelitian seperti yang terlihat pada Gambar 2 dimulai dari studi literatur. Studi literatur merupakan pengumpulan penelitian-penelitian yang pernah dilakukan dan berkaitan dengan penelitian yang sedang dikerjakan. Selain penelitian terdahulu juga dilakukan studi literatur tentang teori yang berkaitan dengan penelitian yang sedang dikerjakan khususnya teori tentang website, evaluasi website, usability, dan usability testing. Tahapan selanjutnya adalah mempelajari website SMK Muhammadiyah 2 Sragen, tujuannya 
adalah untuk menentukan tugas untuk dimasukkan dalam skenario yang akan dikerjakan oleh pengguna ketika melaksanakan pengujian usability.

Perancangan pengujian usability adalah melakukan perencanaan pengujian yang terdiri dari pemilihan partisipan pengujian, lokasi pengujian, dan persiapan alat pengujian usability. Tahap berikutnya adalah pelaksanaan pengujian usability dan hasil pengujian. Analisis data dilakukan setelah pengujian usability selesai dilakukan. Analisis data dilakukan kepada waktu yang dibutuhkan pengguna untuk menyelesaikan skenario tugas.

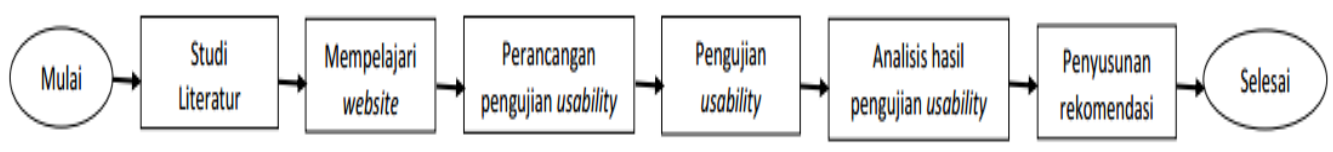

Gambar 2. Langkah Penelitian

\subsection{Alat Dan Bahan}

Pada proses evaluasi website SMK Muhammadiyah 2 Sragen menggunakan beberapa alat dan bahan yang digunakan dalam penelitian ini yaitu :

1) Perangkat keras : (a) Notebook : intel core i3, memori 2 GB, (b) Komputer : intel core i3, memori 2 GB, (c) Smartphone : dual core $1 \mathrm{Ghz}$, memori $1 \mathrm{~GB}$

2) Perangkat lunak : (a) Sistem operasi : windows 8.0 - windows 10 (notebook dan komputer), (b) android 4.1 android 4.3 (smartphone), (c) Camtasia

3) Bahan : (a) Skenario pengujian, (b) Kuisioner, (c) Rekaman video dan catatan mederator

\subsection{Perancangan Pengujian Usability}

Perancangan pengujian usability terdiri dari menentukan partisipan, lokasi pengujian, alat pengujian, dan pelaksanaan pengujian.

1) Pemilihan partisipan

Partisipan yang akan dilibatkan dalam pengujian adalah siswa SMK Muhammadiyah 2 Sragen. Teknik pengumpulan data menggunakan metode purposive sampling, yaitu sampel dipilih berdasarkan jenis kelamin dan pengalaman menggunakan komputer, smartphone dan internet

2) Lokasi pengujian

Lokasi pengujian dilakukan di laboratorium komputer jurusan Teknik Komputer dan Jaringan SMK Muhammadiyah 2 Sragen yang sudah dilengkapi dengan peralatan pengujian. Peralatan pengujian yang digunakan terdiri dari komputer, laptop, smartphone, dan kamera yang akan digunakan sebagai alat dokumentasi selama pengujian.

3) Meterial pengujian

Material pengujian terdiri dari naskah orientasi dan skenario tugas. Material pengujian diberikan kepada partisipan sebagai petunjuk ketika melaksanakan pengujian.

4) Pelaksanaan pengujian

Pengujian dilakukan dengan memberikan kesempatan kepada pengguna untuk mengunjungi website SMK Muhammadiyah 2 Sragen sesuai dengan skenario tugas yang sudah dipersiapkan untuk mengetahui waktu yang diperlukan untuk menyelesaikan penugasan. Pengujian dilakukan dengan memberikan penugasan kepada partisipan untuk mengunjungi website SMK Muhammadiyah 2 Sragen menggunakan perangkat desktop dan mobile.

\section{HASIL DAN PEMBAHASAN}

Pengujian usability menggunakan 15 partisipan yang melakukan pengujian menggunakan perangkat desktop dan 15 partisipan melakukan pengujian menggunakan perangkat mobile. Pengujian usability menggunakan skenario tugas kepada pengguna untuk menemukan informasi di dalam website SMK Muhammadiyah 2 Sragen dan mencari informasi menggunakan kotak pencarian. Skenario tugas seperti yang terlihat pada Tabel 1.

\section{Tabel 1. Skenario tugas}

\begin{tabular}{cl}
\hline No & \multicolumn{1}{c}{ Tugas } \\
\hline 1 & Melihat informasi sarana dan prasarana sekolah \\
2 & Melihat informasi program keahlian Teknik Komputer Jaringan (TKJ) \\
3 & Melihat informasi prestasi siswa \\
4 & Melakukan pencarian dengan kata kunci "sejarah singkat" \\
\hline
\end{tabular}


Analisis data pengujian dilakukan dengan menghitung waktu yang diperlukan oleh partisipan untuk menyelesaikan seluruh tugas yang terdapat dalam skenario tugas. Analisis waktu diperlukan untuk melakukan penilaian efektifitas tampilan antarmuka website SMK Muhammadiyah 2 Sragen. Hasil pengujian usability website SMK Muhammadiyah 2 Sragen seperti yang terlihat pada Tabel 2 dan Tabel 3.

\begin{tabular}{|c|c|c|}
\hline No & Partisipan & Waktu (detik) \\
\hline 1 & Partisipan 1 & 172 \\
\hline 2 & Partisipan 2 & 197 \\
\hline 3 & Partisipan 3 & 200 \\
\hline 4 & Partisipan 4 & 206 \\
\hline 5 & Partisipan 5 & 160 \\
\hline 6 & Partisipan 6 & 142 \\
\hline 7 & Partisipan 7 & 139 \\
\hline 8 & Partisipan 8 & 136 \\
\hline 9 & Partisipan 9 & 190 \\
\hline 10 & Partisipan 10 & 165 \\
\hline 11 & Partisipan 11 & 170 \\
\hline 12 & Partisipan 12 & 264 \\
\hline 13 & Partisipan 13 & 356 \\
\hline 14 & Partisipan 14 & 161 \\
\hline \multirow[t]{2}{*}{15} & Partisipan 15 & 200 \\
\hline & Mean & 190 \\
\hline
\end{tabular}

\begin{tabular}{|c|c|c|}
\hline No & Partisipan & Waktu (detik) \\
\hline 1 & Partisipan 1 & 238 \\
\hline 2 & Partisipan 2 & 256 \\
\hline 3 & Partisipan 3 & 240 \\
\hline 4 & Partisipan 4 & 245 \\
\hline 5 & Partisipan 5 & 222 \\
\hline 6 & Partisipan 6 & 310 \\
\hline 7 & Partisipan 7 & 320 \\
\hline 8 & Partisipan 8 & 322 \\
\hline 9 & Partisipan 9 & 330 \\
\hline 10 & Partisipan 10 & 250 \\
\hline 11 & Partisipan 11 & 235 \\
\hline 12 & Partisipan 12 & 185 \\
\hline 13 & Partisipan 13 & 190 \\
\hline 14 & Partisipan 14 & 182 \\
\hline \multirow[t]{2}{*}{15} & Partisipan 15 & 180 \\
\hline & Mean & 247 \\
\hline
\end{tabular}

Hasil pengujian pada Tabel 2 dan Tabel 3 dapat diambil kesimpulan bahwa waktu rata-rata (mean) yang dibutuhkan oleh partisipan yang menggunakan perangkat desktop dan perangkat mobile ketika menyelesaikan skanario pengujian yang diberikan menunjukkan adanya perbedaan waktu rata-rata. Waktu rata-rata yang dibutuhkan oleh partisipan yang menggunakan perangkat mobile lebih lama apabila dibandingkan dengan partisipan yang menggunakan perangkat desktop.

Berdasarkan hasil pengamatan dan wawancara kepada partisipan saat melaksanakan pengujian usability, perbedaan waktu rata-rata dikarenakan tampilan menu/navigasi yang digunakan pada desain antarmuka website SMK Muhamamdiyah 2 Sragen tidak efektif. Menu/navigasi yang tidak efektif disebabkan oleh banyaknya item yang dimasukkan, seperti yang terlihat pada Gambar 3 dan Gambar 4. Tampilan menu dan submenu pada perangkat desktop tidak mengalami kendala yang berarti, tetapi untuk perangkat mobile menu yang ditampilkan akan terlihat bertumpuk panjang.
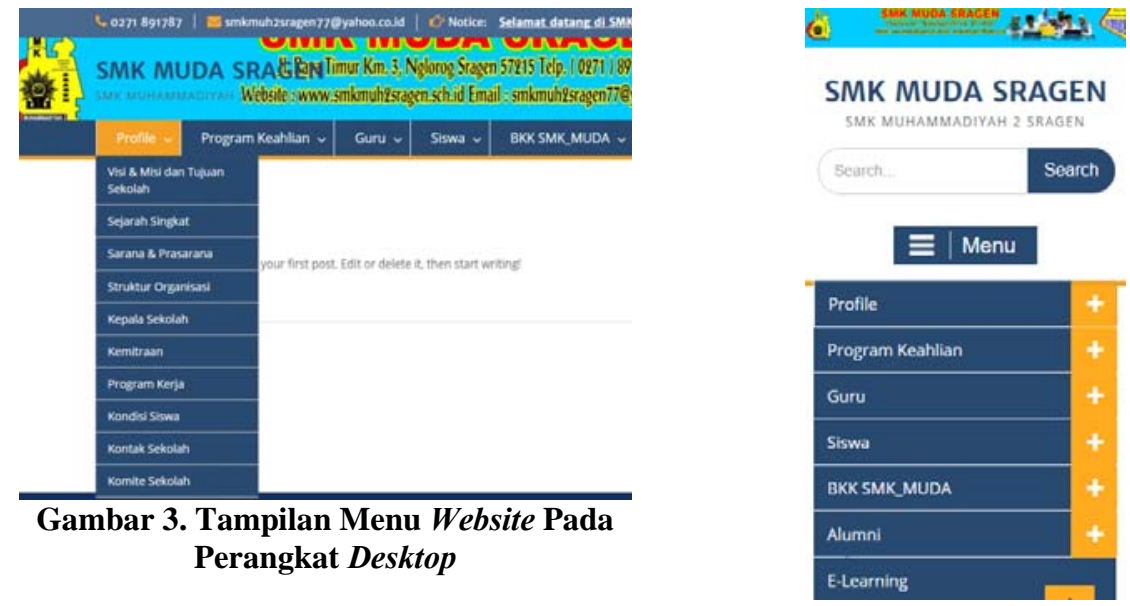

Gambar 4. Tampilan Menu Website Pada Perangkat Mobile

Analisa data kuisioner dilakukan untuk menentukan kategori persentase kelompok berdasarkan jawaban yang sudah diberikan oleh partisipan pada setiap item pertanyaan. Hasil pengolahan data kusioner seperti yang terlihat pada Tabel 4. 
Tabel 4. Hasil pengolahan data kuisioner

\begin{tabular}{clcccc}
\hline \multirow{2}{*}{NNo} & \multicolumn{1}{c}{ Pertanyaan } & \multicolumn{2}{c}{ Perangkat Desktop } & \multicolumn{2}{c}{ Perangkat Mobile } \\
\cline { 2 - 5 } & \multicolumn{1}{c}{ Persentase } & Kriteria & Persentase & Kriteria \\
\hline 1 & $\begin{array}{l}\text { Apakah tampilan website mudah } \\
\text { dikenali? }\end{array}$ & $84 \%$ & Sangat kuat & $76 \%$ & Kuat \\
2 & $\begin{array}{l}\text { Apakah website mudah } \\
\text { dioperasikan? }\end{array}$ & $88 \%$ & Sangat kuat & $80 \%$ & Kuat \\
3 & $\begin{array}{l}\text { Apakah tampilan website enak } \\
\text { dilihat dan tidak membosankan? }\end{array}$ & $70,67 \%$ & Kuat & $70,67 \%$ & Kuat \\
4 & $\begin{array}{l}\text { Apakah tampilan menu dalam } \\
\text { website mudah dikenali? }\end{array}$ & $81,33 \%$ & Sangat kuat & $70,67 \%$ & Kuat \\
5 & $\begin{array}{l}\text { Apakah informasi dalam website } \\
\text { mudah dicari? }\end{array}$ & $82,67 \%$ & Sangat kuat & $72 \%$ & Kuat \\
6 & $\begin{array}{l}\text { Apakah jenis huruf (font) mudah } \\
\text { dibaca? }\end{array}$ & $84 \%$ & Sangat kuat & $78,67 \%$ & Kuat \\
7 & $\begin{array}{l}\text { Apakah simbol/gambar yang } \\
\text { digunakan mudah dipahami? }\end{array}$ & $70,67 \%$ & Kuat & $74,67 \%$ & Kuat \\
8 & $\begin{array}{l}\text { Apakah mudah mengakses } \\
\text { informasi dalam website? }\end{array}$ & $80 \%$ & Kuat & $73,33 \%$ & Kuat \\
9 & $\begin{array}{l}\text { Apakah mudah mengakses } \\
\text { tampilan menu dalam website? } \\
\text { Apakah menu dan tampilan } \\
\text { halaman website mudah diingat? }\end{array}$ & $76 \%$ & Kuat & $58,67 \%$ & Cukup \\
\hline
\end{tabular}

Tabel 4 menunjukkan pengolahan data hasil kuisioner pengguna ketika mengakses website SMK Muhamamdiyah 2 Sragen menggunakan perangkat desktop dan perangkat mobile. Hasil kuisioner secara umum menunjukkan data bahwa tampilan antarmuka website sudah baik, hal tersebut ditunjukkan dengan sebagian besar jawaban kuisoner menunjukkan nilai lebih dari 70\% dengan kriteria kuat sampai dengan sangat kuat. Hasil kurang memuaskan ditemukan pada pertanyaan yang berhubungan dengan implementasi menu pada website. Pengolahan data menunjukkan kriteria cukup pada kemudahan mengingat menu dan tampilan website, selain itu pada pengguna perangkat mobile kemudahan mengakses menu menurut pengguna hanya mendapatkan kriteria cukup. Hasil tersebut menunjukkan bahwa pada implementasi desain menu/navigasi yang sekarang digunakan pada website perlu dilakukan perbaikan khususnya yang akan ditampilkan pada perangkat mobile.

\section{KESIMPULAN}

Kesimpulan dari penelitian yang dilakukan adalah :

1) Tampilan antarmuka website SMK Muhammadiyah 2 Sragen sudah baik, hal ini ditunjukkan dengan sebagian besar jawaban kuisoner menunjukkan nilai lebih dari $70 \%$ dengan kriteria kuat sampai dengan sangat kuat.

2) Implementasi menu/navigasi website SMK Muhammadiyah 2 Sragen tidak efektif pada pengguna perangkat mobile, hal ini dibuktikan dengan adanya perbedaan waktu rata-rata yang lebih lama antara pengguna perangkat mobile dengan pengguna perangkat desktop ketika melaksanakan pengujian usability.

3) Menu/navigasi pada website SMK Muhamamdiyah 2 Sragen memerlukan perbaikan karena kemudahan mengakses dan mengingat menu/navigasi masih kurang memuaskan pengguna perangkat mobile, hal ini ditunjukkan dengan jawaban kuisioner menujukkan nilai sekitar 50\% dengan kriteria cukup.

\section{DAFTAR PUSTAKA}

[1] Sasongko. D. 2016. Pengembangan Antarmuka Perpustakaan Digital Menggunakan Responsive Web Design Dengan Pendekatan User Experience (Studi Kasus Pada Perpustakaan Digital Universitas Surakarta), Tesis, Universitas Gadjah Mada Yogyakarta.

[2] Sasongko, D. et al., 2016. The Development of Digital Library User Interface by Using Responsive Web Design and User Experience, Indonesian Journal of Electrical Engineering and Computer Science, 4(1).

[3] Purwani I., 2011. Evaluasi Usability Situs Web Perpustakaan, Majalah Visi Pustaka, vol. 13, No.3.

[4] Purwani I., Eko N., 2012. Evaluasi Situs Web Perpustakaan Fakultas Geografi Universitas Gadjah Mada, Universitas Gadjah Mada. 
Jurnal SIMETRIS, Vol 8 No 1 April 2017

ISSN: 2252-4983

[5] Wahyu H et. al., 2014. Penerapan Metode Usability Testing Pada Evaluasi Situs Web Pemerintahan Prabumulih, Jurnal Mahasiswa Teknik Informatika. 